Doi: HTTPS://DOI.ORG/10.23910/IJBSM/2017.8.5.1802a

\title{
Influence of Manual and Chemical Thinning on Yield and Quality of Nectarine [Prunus persica (L.) Batsch var. nucipersica] cv. Snow Queen
}

\author{
Rajiv Kumar, Rimpika, N. Sharma, Bunty Shylla*, Anju Thakur and D. P. Sharma
}

Dept. of Fruit Science, Dr. Y. S. Parmar University of Horticulture and Forestry, Nauni, Solan, H.P. (173 230), India

\author{
Corresponding Author \\ Bunty Shylla \\ e-mail: shyllabunty@yahoo.com
}

\author{
Article History \\ Article ID: AR1802a \\ Received in $5^{\text {th }}$ March, 2017 \\ Received in revised form 15 $5^{\text {th }}$ April, 2017 \\ Accepted in final form $30^{\text {th }}$ April, 2017
}

\begin{abstract}
Stone fruits have been found to be highly suitable to the mid hill zone of Himachal Pradesh. Among these fruits, nectarine is fast emerging as one of the important and potential fruit due its attractive appearance and better remuneration as compared to peaches. Among the various cultivars of nectarines being cultivated in this Zone, Snow Queen is the most important cultivar. But under congenial agro climatic conditions, it invariably bears copiously resulting in small to medium sized fruits which consequently fetches low price in the market. Hence the present studies have been carried out with the objective to study the influence of manual and chemical thinning on the fruit yield and quality of Snow Queen Nectarine during 2012 and 2013. Experimental trees were subjected to different treatments viz. retention of 3,4 and 5 fruits manually, foliar application of Ethrel at 200 and 300 ppm, NAA at 20 and 40 ppm, TDZ at 20 and 40 ppm, Ethrel at 200 ppm+NAA at $20 \mathrm{ppm}$, Ethrel at $200 \mathrm{ppm}+\mathrm{TDZ}$ at $20 \mathrm{ppm}$ and control (water spray) two weeks after petal fall, with three replications using RBD. Hand thinning to retain 3 fruits shoot ${ }^{-1}$ registered the highest thinning percentage, fruit size, weight and volume with the lowest yield. The fruits of the trees treated with Ethrel at $300 \mathrm{ppm}$ recorded the highest content of TSS, total sugar, reducing sugar as well as fruit colouration while fruit acidity and firmness were the lowest in these fruits.
\end{abstract}

Keywords: Thinning, yield, quality, nectarine, snow queen

\section{Introduction}

Nectarines (Prunus persica (L.) Batsch Var. nucipersica) are the group of peaches often referred to as "fuzzy-less peaches" or "shaven peaches" due to the lack of fuzz or short hair on the fruit surface. The absence of fuzz (pubescence) on the nectarine fruit surface giving it a smooth skin appearance is fundamentally the only difference between peach and nectarine, though fuzzy peaches and nectarines are often commercially regarded as different fruits. In Himachal Pradesh, its commercial cultivation is catching up in the midhill zones comprising districts of Kullu, Solan and Sirmour though it can also be extended to the other sub humid mid-hill areas of Chamba, Mandi, Shimla and Kangra district. Due its attractive appearance and better remuneration in comparison to peaches, nectarine is fast emerging as one of the important and potential stone fruit of Himachal Pradesh.

Among the various cultivars of nectarines, Snow Queen is the most important cultivar in the state. Its fruits are very attractive having bright red skin colour with white flesh, cling stone and excellent flavour. Under congenial agro climatic conditions, this cultivar invariably bears copiously with small to medium sized fruits which consequently fetches low price in the market. Further, Heavy crop load also results in breakage of limbs and exhaustion of tree reserves (Dennis, 2002). For profitable nectarine production, it is very important to have large and uniform sized fruits. Thinning is one of the important agro techniques that can improve fruit size, colour and quality, besides reducing limb breakage and promoting general tree vigour. Thinning lessens the demand on the tree's resources so that it is able to make good growth and develop fruit buds for the following year thus avoiding the risk of biennial bearing. It allows sunlight and air to penetrate the branches which improves evenness of ripening. Traditionally, thinning of blossoms or fruit-lets is usually carried out manually. However, this practice is time consuming, labour intensive and expensive. Therefore, the trend has shifted towards chemical thinning using different chemicals such as carbaryl, dinitro compounds, plant growth regulators like Ethrel, NAA, thidiazuron etc. Chemical thinning can be done at pre-bloom, bloom and post-bloom stages; thinning at the earlier two stages is based on the crop potential, whereas thinning at later stage is done only after assessing the actual crop load and is a better practice under Indian agro-climatic conditions. However, under the Indian agro-climatic condition, nectarine being a newly 
introduced crop, not much work has been done on the use of chemical thinning of fruits. Hence the present studies have been carried out with the objective to study the influence of manual and chemical thinning on the fruit yield and quality of Snow Queen Nectarine.

\section{Materials and Methods}

The trial was carried out on six-year old trees of nectarine cultivar Snow Queen raised on seedling rootstocks at $2 \times 3$ meter spacing and trained as open centre at the Experimental Orchard of the Department of Fruit Science, Dr. Y.S. Parmar University of Horticulture and Forestry, Nauni, Solan, Himachal Pradesh, during the years 2012 and 2013 in a Randomized Block Design with twelve treatments and three replications. For the present study, 36 trees of uniform vigour were selected and were kept under uniform cultural practices. The treatment details include $T_{1}=$ Retention of 3 fruits shoot ${ }^{-1}$; $\mathrm{T}_{2}=$ Retention of 4 fruits shoot ${ }^{-1} ; \mathrm{T}_{3}=$ Retention of 5 fruits shoot $^{-1} ; \mathrm{T}_{4}=$ Ethrel $200 \mathrm{ppm} ; \mathrm{T}_{5}=$ Ethrel $300 \mathrm{ppm} ; \mathrm{T}_{6}=\mathrm{NAA}$ 20 ppm; $T_{7}=$ NAA 40 ppm; $T_{8}=T D Z 20$ ppm; $T_{9}=T D Z 40$ ppm; $\mathrm{T}_{10}=$ Ethrel $200 \mathrm{ppm}+\mathrm{NAA} 20 \mathrm{ppm} ; \mathrm{T}_{11}=$ Ethrel 200 ppm+TDZ 20 ppm; $T_{12}=$ Control (No thinning). Hand and chemical thinning treatments were carried out two weeks after petal fall, when fruitlets were approximately of pea size. Per cent fruit thinning per treatment were calculated by using the following formula

Thinning percentage $=\frac{\text { Initial fruit set-Final fruit set }}{\text { Initial fruit set }} \times 100$

The fruit retained after thinning were taken as yield. Fruit size in terms of length and breadth of ten randomly selected fruits per replication was recorded with a Digital calliper. Fruit breadth was worked out by averaging the values of cheek and suture diameter which had been recorded separately. The selected fruits taken for recording the fruit size data were weighed on electronic top pan balance and the average fruit weight was expressed in gram per fruit $\left(\mathrm{g} \mathrm{fruit}^{-1}\right)$. Volume of fruits was measured by water displacement method. Selected fruits taken for measuring size and weight were immersed in a measuring cylinder filled with water up to a certain graduation. The difference between initial and final readings gave the measurement of volume of fruit samples. The fruit firmness was determined by a pressure tester (Magness-Taylor) which recorded the pressure necessary for the plunger to penetrate the peeled flesh of nectarine fruits. Skin colour of randomly selected fruits was determined as per 4 point scale $(<25 \%$ colour $=1 ; 25-49 \%$ colour $=2 ; 50-74 \%$ colour $=3$ and $>75 \%$ colour $=4)$. The total soluble solids content in fruits were determined by Erma hand refractometer (0-32 Brix). Total sugars of the fruits were estimated by volumetric method suggested by A.O. A.C., in 1980. The total titratable acidity was calculated in terms of malic acid on the basis of one $\mathrm{ml}$ of $0.1 \mathrm{~N} \mathrm{NaOH}$ equivalents to $0.0067 \mathrm{~g}$ of anhydrous malic acid. The TSS/acid ratio was obtained by dividing the corresponding value of total soluble solids to the malic acid content of the fruit juice.

\section{Results and Discussion}

In this investigation, the different treatments exerted a significant effect on per cent fruit thinning. Among all the treatments, hand thinning treatment involving retention of three fruits per shoot gave highest fruit thinning percentage (Table 1), followed by hand thinning treatments of retaining four and five fruits shoot ${ }^{-1}$, in the decreasing order. These results are on the expected line and in agreement with the earlier findings (Sharma et al., 2001) that fruit thinning percentage increased with the increase in the severity of thinning in peaches. The results with respect to NAA effects on fruit thinning in the present study are in line with the earlier findings that NAA applied two to three weeks after petal fall induced optimum thinning in peach (Brar et al., 1992; Sharma et al., 2003) and in nectarine (Rimpika, 2012).

A perusal of Table 1 reveals that different thinning treatments significantly decreased average fruit yield in comparison to control. In the study, reduction in total fruit yield may be the direct result of reduction in crop load because of the removal of fruits in the thinning operation. Similarly, other workers (Mohsen 2010; El-Boray et al., 2012) observed a significant reduction in the total fruit yield of peach $\mathrm{cv}$. Floridaprince in comparison to control, when the blossoms were spaced at 20 $\mathrm{cm}$ on shoots by hand thinning. Casierra et al., in 2007 also recorded a reduced total yield at harvest in the hand thinned trees of peach (Prunus persica L. Batsch cv. 'Rubidoux'), though the marketable fruit yield was improved. The results are in conformity with the earlier findings that fruit thinning with NAA lead to a decrease in average yield and increase in the production of marketable fruits in peach (Sharma et al., 2003) and nectarine (Rimpika et al., 2015).

Different fruit thinning treatments have exerted a noticeable influence on fruit size, weight and volume, in the present study. The results presented in Table 1, revealed that these attributes of fruits were improved significantly with the hand thinning treatment to retain 3 fruits shoot ${ }^{-1}$ and applications of NAA at 40 ppm over the control. The results obtained are in conformity with earlier findings that the selective removal of blossoms or young fruitlets increased fruit size and weight in peaches and nectarine (Sharma et al., 2003; Rimpika, 2012; El-Boray et al., 2012). The findings pertaining to the application of NAA are also in accordance with those of Sharma et al., in 2003; Rimpika in 2015, who observed that its application, 2-3 weeks after petal fall significantly increased fruit size and weight in "Redhaven" peach and "May Fire" nectarine, respectively. However, the increase in fruit size and weight by auxin may not be entirely due to the reduction in crop competition, but also be due to the direct effect of auxin on sink strength of the fruit (Guardiola and Luis, 1997).

Higher firmness (Table 1) was noted in fruits from trees treated with thidiazuron at $40 \mathrm{ppm}$ and un-thinned control. 
Table 1: Effect of manual and chemical thinning on fruit thinning, fruit yield and physical characteristics in nectarine cv. Snow Queen (pooled data)

\begin{tabular}{lcccccccc}
\hline Treatment & $\begin{array}{c}\text { Fruit thinning } \\
(\%)\end{array}$ & $\begin{array}{c}\text { Total fruit } \\
\text { yield } \\
\left(\mathrm{kg} \mathrm{tree}^{-1}\right)\end{array}$ & $\begin{array}{c}\text { Fruit } \\
\text { Length } \\
(\mathrm{mm})\end{array}$ & $\begin{array}{c}\text { Fruit } \\
\text { breadth } \\
(\mathrm{mm})\end{array}$ & $\begin{array}{c}\text { Fruit } \\
\text { weight } \\
(\mathrm{g})\end{array}$ & $\begin{array}{c}\text { Fruit } \\
\text { volume } \\
(\mathrm{cc})\end{array}$ & $\begin{array}{c}\text { Fruit } \\
\text { firmness } \\
\left(\mathrm{kg} \mathrm{cm}^{-2}\right)\end{array}$ & $\begin{array}{c}\text { Fruit } \\
\text { colouration } \\
(4 \text { pt.scale) }\end{array}$ \\
\hline Retention of 3 fruits shoot $^{-1}$ & $53.54(47.02)$ & 5.08 & 52.40 & 50.83 & 65.15 & 67.68 & 7.47 & 2.88 \\
Retention of 4 fruits shoot $^{-1}$ & $48.93(44.37)$ & 5.84 & 49.31 & 45.34 & 56.46 & 58.28 & 7.05 & 2.53 \\
Retention of 5 fruits shoot $^{-1}$ & $46.86(43.19)$ & 6.37 & 48.95 & 45.01 & 54.70 & 56.60 & 6.87 & 2.55 \\
Ethrel 200 ppm $_{\text {Ethrel 300 ppm }}^{30.45(33.46)}$ & 7.60 & 49.28 & 44.79 & 55.02 & 56.72 & 6.56 & 2.82 \\
NAA 20 ppm & $33.64(35.34)$ & 6.99 & 49.00 & 44.10 & 53.62 & 55.32 & 6.38 & 3.45 \\
NAA 40 ppm & $29.51(32.08)$ & 7.82 & 50.73 & 45.88 & 57.85 & 59.88 & 7.55 & 2.85 \\
TDZ 20 ppm & $34.40(35.90)$ & 7.30 & 51.97 & 47.96 & 62.27 & 63.87 & 7.73 & 3.15 \\
TDZ 40 ppm & $28.23(32.08)$ & 7.88 & 49.61 & 43.11 & 50.97 & 52.78 & 7.92 & 2.03 \\
Ethrel 200 ppm+NAA 20 & $30.92(33.77)$ & 7.73 & 49.15 & 43.93 & 54.96 & 56.65 & 8.86 & 2.23 \\
ppm & $33.90(35.59$ & 7.58 & 49.73 & 44.46 & 54.76 & 56.58 & 7.40 & 2.52 \\
Ethrel 200 ppm+TDZ 20 & $34.77(36.12)$ & 7.13 & 51.02 & 46.28 & 58.14 & 60.15 & 8.07 & 2.85 \\
ppm & & & & & & & & \\
Control (No thinning) & $23.28(28.82)$ & 9.22 & 40.98 & 37.08 & 37.84 & 39.83 & 8.79 & 1.69 \\
CD ( $p=0.05)$ & 1.60 & 0.82 & 3.28 & 2.99 & 6.36 & 6.20 & 0.24 & 0.53 \\
\hline
\end{tabular}

However, Ethrel treatment at $300 \mathrm{ppm}$ decreased the firmness, significantly. In the present study, despite increase in fruit size, thidiazuron treatment might have maintained fruit firmness in parallel with un-thinned control because of its anti-senescence properties (Carimi et al., 2003). The present findings are in accordance with earlier findings that thinning with thidiazuron lead to an increase in flesh firmness in nectarine (Rimpika, 2012). The results relating to the decrease in fruit firmness with Ethrel treatment are in agreements with the earlier finding of Taheri et al. (2012) in peach. Ethylene plays a major role in acceleration of the onset of climacteric behaviour due to which, certain enzymatic activities bring about changes associated with ripening, resulting in softening of fruit along with an increase in soluble pectin substances and decrease in insoluble pectin substances as well as firmness and can be attributed to depolymerisation and de-esterification (Dhillon and Bhatt, 2011).

However, the increase in skin colouration (Table 1) was more pronounced on fruits treated with Ethrel at higher concentration. Higher colour development in Ethrel treated fruit in the present study may be due to enhancement of ripening (Taheri et al., 2012) and anthocyanin pigmentation (Whale et al., 2012) as induced by ethylene. Earlier, improved fruit skin colour with foliar application of Ethrel has also been reported in peach cultivar Redhaven (Sharma et al., 2001) and nectarine cultivar May Fire (Rimpika et al., 2014).

The results presented in Table 2 reveals that total soluble solids, titratable acidity and sugar contents were variably influenced by different thinning treatments. It was noted that Ethrel treatments applied at 200 or 300 ppm significantly increased the total soluble solids and sugar contents of fruits and decreased the fruit titratable acidity. Similar findings of increased fruit TSS and sugar contents and decreased fruit acidity following post bloom application of Ethrel was also reported by Sharma et al., 2001; Taheri et al., 2012 in peaches and by Rimpika et al., 2014 in nectarines. The metabolic changes during the fruit ripening particularly an increase

Table 2: Effect of manual and chemical thinning on fruit chemical characteristics in nectarine cv. Snow Queen (pooled data)

\begin{tabular}{lccccc}
\hline Treatment & TSS & TA & TS & RS & NRS \\
\hline $\begin{array}{l}\text { Retention of } 3 \\
\text { fruits shoot }\end{array}$ & 11.62 & 0.50 & 8.80 & 3.29 & 5.23 \\
$\begin{array}{l}\text { Retention of 4 } \\
\text { fruits shoot }^{-1}\end{array}$ & 11.11 & 0.52 & 8.70 & 3.29 & 5.14 \\
$\begin{array}{l}\text { Retention of } 5 \\
\text { fruits shoot }^{-1}\end{array}$ & 11.91 & 0.49 & 9.33 & 3.48 & 5.55 \\
Ethrel 200 ppm & 12.14 & 0.47 & 9.52 & 3.60 & 5.63 \\
Ethrel 300 ppm & 12.94 & 0.41 & 10.15 & 3.81 & 6.03 \\
NAA 20 ppm & 12.09 & 0.49 & 9.49 & 3.56 & 5.63 \\
NAA 40 ppm & 11.39 & 0.52 & 8.96 & 3.36 & 5.32 \\
TDZ 20 ppm & 10.91 & 0.50 & 8.57 & 3.23 & 5.08 \\
TDZ 40 ppm & 10.59 & 0.53 & 8.32 & 3.11 & 4.95 \\
\hline & & & & \multicolumn{3}{c}{ Continue.. }
\end{tabular}




\begin{tabular}{lccccc}
\hline Treatment & TSS & TA & TS & RS & NRS \\
\hline $\begin{array}{l}\text { Ethrel 200 ppm } \\
\text { +NAA 20 ppm }\end{array}$ & 11.19 & 0.49 & 8.78 & 3.31 & 5.20 \\
$\begin{array}{l}\text { Ethrel 200 } \\
\text { ppm+ TDZ 20 } \\
\text { ppm }\end{array}$ & 11.08 & 0.50 & 8.71 & 3.26 & 5.18 \\
$\begin{array}{l}\text { Control (No } \\
\text { thinning) }\end{array}$ & 9.14 & 0.62 & 7.18 & 2.70 & 4.26 \\
CD $(p=0.05)$ & 0.85 & 0.07 & 0.57 & 0.21 & 0.35 \\
\hline
\end{tabular}

TSS: Total soluble solids ('Brix); TA: Titratable acidity (\%); TS: Total sugars (\%); RS: Reducing sugar (\%); NRS: Non reducing sugar (\%)

in the biosynthesis and evolution of the ripening hormone ethylene was also obswerved by Yang and Hoffman in 1984 and also reported by Chandel and Singh in 2015. Enhanced skin colour, total soluble solids, and decreased firmness indicate the effect of ethylene on fruit ripening (Haithem and Abubakr, 2003). In the present study, the exogenous application of Ethrel may have enhanced the internal fruit ethylene concentration, triggered the ripening process and activated the enzymes responsible for hydrolysis of starch into sugar i.e. sucrose, glucose and fructose, and consequently, enhanced the total soluble solids, total sugars, reducing sugars and non reducing sugars and decreased the acidity. Furthermore, increased fruit sugar in these treatments can be attributed to the reduced fruit load and higher photosynthetic rate and consequently more supply of carbohydrates and metabolites to the developing fruits.

\section{Conclusion}

Manual thinning to retain 3 fruits shoot ${ }^{-1}$ can give better thinning percentage with better fruit quality in terms of fruit size, volume and weight in nectarine cv. Snow Queen while Ethrel at $300 \mathrm{ppm}$ can give better fruit quality in terms of increased total soluble solids and sugar contents of fruits and decreased fruit titratable acidity.

\section{References}

A.O.A.C. 1980. Official methods of analytical chemists, $13^{\text {th }}$ ed. Hortwitz, W. (Ed.), Association of Official Chemists. 33, 617-623.

Brar, S.S., Kanwar, J.S., Grewal, S.S., Chanana, Y.R., Kaundal, G.S., 1992. Effects of urea, 2-choloroethyl phosphonic acid and NAA on fruit thinning, yield and quality of peach cv. Flordasun. NHB Technical Communication. 1, 246-250.

Carimi, F., Zottini, M., Formentin, E., Terzim, M., Lo Schiavo, F., 2003. Cytokinins: new apoptotic inducers in plants. Planta 216, 413-421.
Casierra Posada, F., Rodriguez Puerto, J.I., Cardenas Hernandez, J., 2007. Leaf to fruit ratio affects yield, fruit growth and fruit quality of peach (Prunus persica L. Batsch, cv. 'Rubidoux'). Revista Facultad Nacional de Agronomia Medellin 60(1), 3657-3669.

Chandel, J.S., Singh, J., 2015. Effect of chemical and hand thinning on growth, yield and fruit quality of nectarine (Prunus persica Batsch var. nucipersica). Indian Journal of Horticulture 72(1), 28-32.

Dennis, F., Jr. G., 2002. The history of fruit thinning. Journal of Plant Growth Regulators 31, 1-16.

Dhillon, W.S., Bhat, Z.A., 2011. Fruit Tree Physiology. Narendra Publishing House, New Delhi, Pages.

El-Boray, M.S., Shalan, A.M., Khouri, Z.M., 2012. Effect of different thinning techniques on fruit set, leaf area, yield and fruit quality parameters of Prunus persica L. Batsch cv. Floridaprince. Trends in Horticultural Research, 1-13.

Guardiola, J.L., Luis, A.G., 1997. Thinning effect on citrus yield and fruit sized. Acta Horticulturae 463, 463-473.

Haithem, E.M., Abu-bakr, A.A., 2003. Effect of ethrel in aquous solution and ethylene released from ethrel on mango fruit ripening. Plant Growth Regulators 43, 109-115.

Mohsen, A.T., 2010. Thinning time and fruit spacing influence on maturity, yield and fruit quality of peach. Journal of Horticultural Science and Ornamental Plants 2, 79-87.

Rimpika, Sharma, N., Shylla, B., 2014. Effect of manual and chemical thinning on graded yield and fruit quality in nectarine cv. May Fire. Himachal Journal of Agricultural Research 40(1), 26-33.

Rimpika, Sharma, N., Sharma, D.P., Shylla, B., 2015. Effect of hand and chemical thinning on growth production and fruit size in nectarine [Prunus persica (L.) Batsch var. nucipersica] cv. May Fire. Indian Journal of Horticulture 72 (2), 282-284.

Sharma, N., Singh, R.P., Singh, B., 2001. Influence of chemical and hand thinning on maturity, quality and colour of fruits in Redhaven peaches. Horticultural Journal 14(3), 6-10.

Sharma, N., Singh, R.P., Singh, B., 2003. Effect of chemical and manual thinning on productivity and fruit size of Redhaven peach. Indian Journal of Horticulture 60(3), 239-243.

Taheri, A., Cline, J.A., Jayasankar, S., Pauls, P.K., 2012. Ethephon induced abscission of "redhaven"peach. American Journal of Plant Sciences 3(2), 295-301.

Whale, S., Singh, J., Janes, J., 2012. Ethylene biosynthesis and fruit color development in 'Pink Lady' apples during growth and maturation. Hort Science 39(4), 762.

Yang, S.F., Hoffman, N.E., 1984. Ethylene biosynthesis and its regulation in higher plants. Annual Review of Plant Physiology 35, 155-189. 